\title{
Is the Diagnosis of Pulmonary Embolism
Using Scoring Systems Still a Dilemma?: A Case Report
}

\author{
Pulmoner Emboli Tanısı Hala Bir Íkilem mi? Hangi Skorlama Sistemi Bizi Tanı- \\ ya Götürür?: Olgu Sunumu
}

Alten Oskay, Cihangir Çelik, Kıvanç Karaman, Hamit Hakan Armağan, Önder Tomruk

\begin{abstract}
Various scoring systems are used to facilitate the diagnosis of pulmonary embolism (PE), provide for the safe discharge of patients from emergency departments (EDs), and protect patients from complications caused by ionizing radiation and iodinated contrast media. A 66-year-old active male patient was brought to the ED due to syncope. He complained of a stinging type of chest pain, hemoptysis, and a mild feeling of retrosternal distress. He had hypoxemia $\left(\mathrm{SpO}_{2}=88 \%\right)$. The D-dimer level determined was $165 \mathrm{ng} / \mathrm{mL}$ (normal range: 69-243 $\mathrm{ng} / \mathrm{mL}$ ). He was evaluated to be at low risk using the Wells Criteria, to have a $2 \%$ probability of PE according to the rGeneva scoring system when viewed in combination with D-dimer negativity, and PE was excluded using the YEARS algorithm. However, computerized tomography pulmonary angiography revealed $P E$ in 2 main pulmonary arteries. The common scoring systems may fail to recognize PE, which requires treatment. Clinical perception may still be superior.
\end{abstract}

Key words: Clinical probability, D-dimer, Diagnostic algorithms, Emergency department, Pulmonary embolism.

\section{Özet}

Pulmoner emboli (PE) tanısını kolaylaştırmak, hastaların acil servisten güvenle taburculuğunu sağlayabilmek, hastaları iyonizan radyasyon ve opak maddelerin komplikasyonlarından koruyabilmek için çeşitli skorlama sistemleri kullanılmaktadır. Altmış altı yaşında aktif erkek hasta acil servise geçirmiş olduğu senkop nedeniyle getirildi. Hasta batıcı tarzdaki göğüs ağrısından, hemoptizi ve hafif bir retrosternal sıkıntı hissinden şikayetçiydi. Vital bulgularında hipoksemisi $\left(\mathrm{SpO}_{2}=88 \%\right)$ mevcuttu. D-dimer değeri $165 \mathrm{ng} / \mathrm{mL}$ (normal sınırlar: 69-243) olarak saptandı. PE olasılığı 2 kategorili Wells'te düşük, D-dimer negatifliği ile birlikte değerlendirilen rGeneva skorlama sistemlerinde \%2 olarak öngörülmesine ve YEARS skalasında tamamen dışlanmasına rağmen hastaya pulmoner bilgisayarlı tomografi anjiografi çekildi. Her iki ana pulmoner arterde pulmoner emboli saptandı. Sıklıkla kullanılan skorlama sistemlerinin tedavi gerektiren PE'yi tanımakta yetersiz kalabildikleri görülmektedir. Klinik algının üstün olduğu bazı noktalar hala vardır.

Anahtar Sözcükler: Acil servis, D-dimer, Klinik olasılık, Klinik skorlama sistemleri, Pulmoner emboli.

Department of Emergency Medicine, Suleyman Demirel University, Süleyman Demirel Üniversitesi Tıp Fakültesi, Acil Tıp Anabilim Isparta, Turkey Dali, Isparta

Submitted (Başvuru tarihi): 10.07.2018 Accepted (Kabul tarihi): 26.09.2018

Correspondence (iletişim): Alten Oskay, Department of Emergency Medicine, Suleyman Demirel University, Isparta, Turkey

e-mail: oskayten@gmail.com 
Pulmonary embolism (PE) is a venous thromboembolism that can appear with a wide variety of nonspecific symptoms (1). It is one of the differential diagnoses of chest pain. Due to the high mortality and morbidity and resulting medicolegal issues associated with $\mathrm{PE}$, it is one of the diagnoses that emergency physicians must bear in mind when assessing patients. The 3-month mortality has been reported to be $5 \%$ in emergency patients who were diagnosed with PE but did not receive any treatment (2). PErelated mortality has been reported to be $1.1 \%$, and 30 day all-cause mortality has been reported to be $5.4 \%$ in patients diagnosed with PE (1).

Many scoring systems have been developed to facilitate PE diagnosis in order to provide for the safe discharge of patients from emergency departments (EDs), protect patients from complications caused by ionizing radiation and iodinated contrast media, and reduce mortality (3-5). In addition to these scoring systems, anamnesis results, vital findings, and physical examination and electrocardiogram (ECG) findings can be used in conjunction with blood D-dimer levels to determine whether patients need further examination in terms of PE.

D-dimer is a biomarker that is formed after fibrin degradation. Quantitative D-dimer measurements using immunoturbidimetric methods based on the agglutination of particles coated with specific monoclonal antibodies have demonstrated a sensitivity and a negative predictive value close to $100 \%(6,7)$. It has been proposed that negative D-dimer levels can be used to exclude PE in patients with low-probability (3) and it also seems to eliminate the need for computed tomography pulmonary angiography (CTPA) in high-risk populations (7). Negative D-dimer $(<500 \mathrm{ng} / \mathrm{mL})$ levels have been reported to be sufficient to exclude PE, even in the presence of clinical support and/or the most probable diagnosis of PE (5).

\section{CASE}

A 66-year-old active male patient was brought to the ED due to syncope. He felt sick and had experienced an episode of syncope that lasted for 2 to 3 minutes in the morning hours. The patient complained of a stinging type of pain in his chest ongoing for 3 days and hemoptysis for 2 days. A pain experienced in the right calf of his leg a week earlier resolved spontaneously without any additional symptoms. The patient had no history of chronic disease or drug use. He only had a feeling of retrosternal distress while he was at the ED. His blood pressure was $130 / 70 \mathrm{mmHg}$, pulse rate 92 beats/minute, respiratory rate 20 /minute, body temperature $36.8^{\circ} \mathrm{C}, \mathrm{SpO}_{2} 88 \%$, and fingertip blood sugar value was 151. His physical examination was normal. His ECG results indicated a sinus rhythm with an incomplete right bundle branch block and S1Q3 pattern (Figure 1). The D-dimer and high-sensitive troponin $T$ levels were $165 \mathrm{ng} / \mathrm{mL}$ (automated latex-enhanced immunoassay; normal range: 69$243 \mathrm{ng} / \mathrm{mL}$ ) and $0.01 \mathrm{ng} / \mathrm{mL}$ (normal range: 0-0.014), respectively. Other laboratory analyses of creatinine, liver enzymes, and electrolyte levels were in the normal range. A slight right diaphragm elevation was detected in the posteroanterior chest X-ray (Figure 2). Right ventricular dilatation was observed on a bedside ultrasound performed. CTPA results were interpreted as revealing some filling defects compatible with total/partial emboli at the distal end of both main pulmonary arteries and extending to all lobular pulmonary arteries. The diameter of the pulmonary trunk, the right main pulmonary artery, and the left main pulmonary artery was $29 \mathrm{~mm}, 25 \mathrm{~mm}$, and $23 \mathrm{~mm}$, respectively (Figure 3). Rt-PA was administered to the patient. He was transferred to the pulmonology clinic ward where warfarin therapy was initiated during the follow-up. According to archive records, the patient's complaints resolved and he was discharged to continue therapy on an outpatient basis.

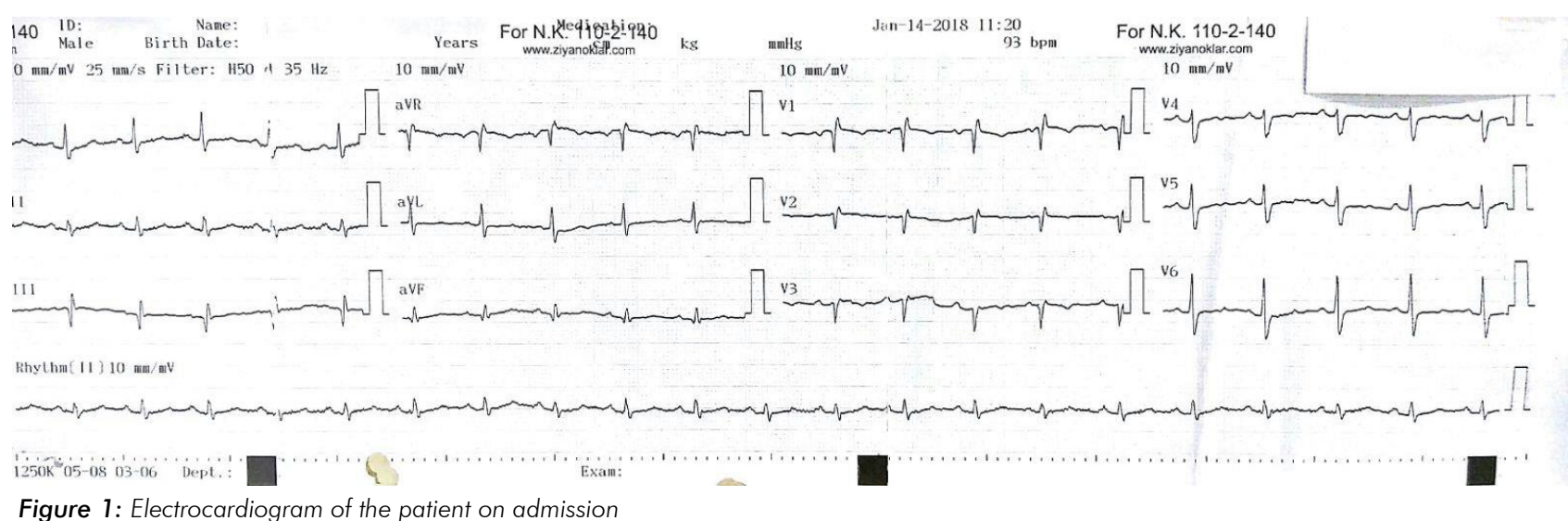




\section{DISCUSSION}

$\mathrm{PE}$ is a venous embolus usually originating from the deep veins of the legs. The most common symptom of this disease is dyspnea (50\%), followed by pleuritic chest pain (39\%), cough (23\%), substernal pain (15\%), fever (10\%), hemoptysis (8\%), syncope (6\%), unilateral leg pain (6\%), and signs of deep vein thrombosis (24\%) (1).

Various clinical scoring systems are used to assess the probability of PE in EDs. Two of these are the Wells Criteria (3) and a revised Geneva scoring system (4), both of which are often used in our clinic.

The result of a multicenter study in the Netherlands, published in 2017, is known as the YEARS algorithm (5). It was proposed that that PE diagnosis may be directly excluded when the D-dimer level is below $500 \mathrm{ng} / \mathrm{mL}$ with 1 or more criteria in the list, including hemoptysis, deep venous thrombosis, and the most probable diagnosis of $P E$, without suggesting any additional imaging analysis (5).

In our case, the Wells score was 4 points (alternative diagnosis less likely than PE: 3 points, hemoptysis: 1 point). According to the two-tier model, the diagnosis of PE was unlikely, and the probability of PE was $1.7 \%$ when taking the D-dimer negativity into consideration. The 3tier method indicated a moderate risk of $18.8 \%$ (3).

The rGeneva system evaluation yielded a score of 9 points (age $>65$ years: 1 point, unilateral extremity pain:

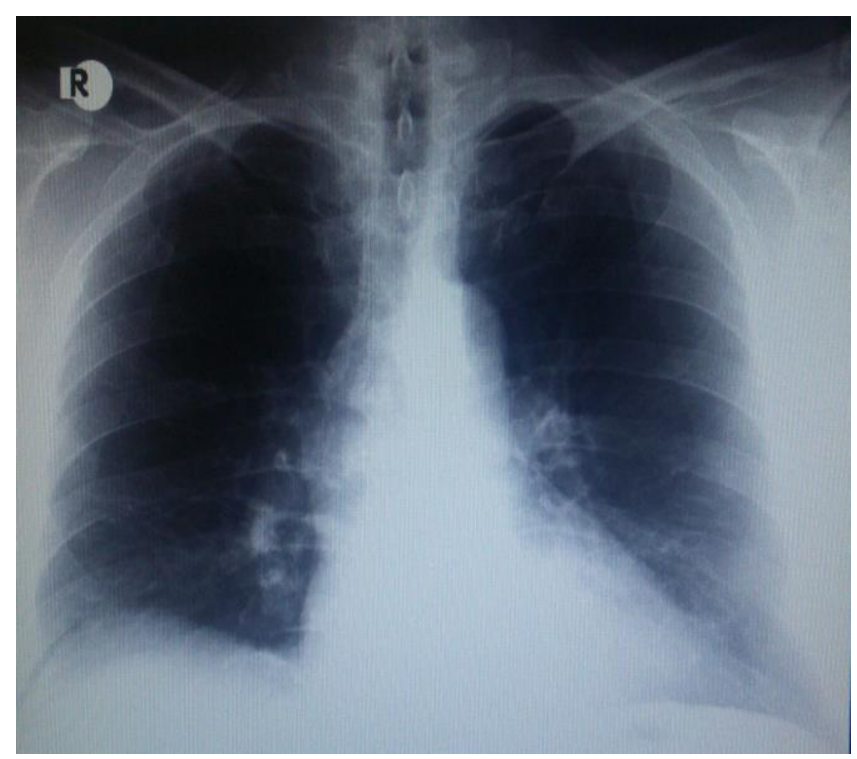

Figure 2: Posteroanterior chest $x$-ray on admission
3 points, hemoptysis: 2 points, heart rate 75-94 bpm: 3 points), which indicated a medium clinical probability. The probability of PE was $2 \%$ when these results were evaluated together with D-dimer negativity (4).

A study comparing clinical perception and Wells scoring combined with the qualitative D-dimer measurement showed that both low-probability rating in Wells and clinical perception could be used confidently for PE exclusion (8). When the rGeneva score was compared with the Wells score, the latter was found to be better in assessing the high probability of PE (9). In another study, it was concluded that clinical perception, which increased with clinical experience, was not less valuable compared with classical clinical scoring systems for determining prognosis in acute symptomatic PE (10).

\section{CONCLUSION}

Although many scoring systems have been developed and even more useful and simple tools are still being developed, it is clear that common scoring systems may fail to recognize $P E$, which requires treatment. Clinical perception and experience are still invaluable.

\section{CONFLICTS OF INTEREST}

None declared.

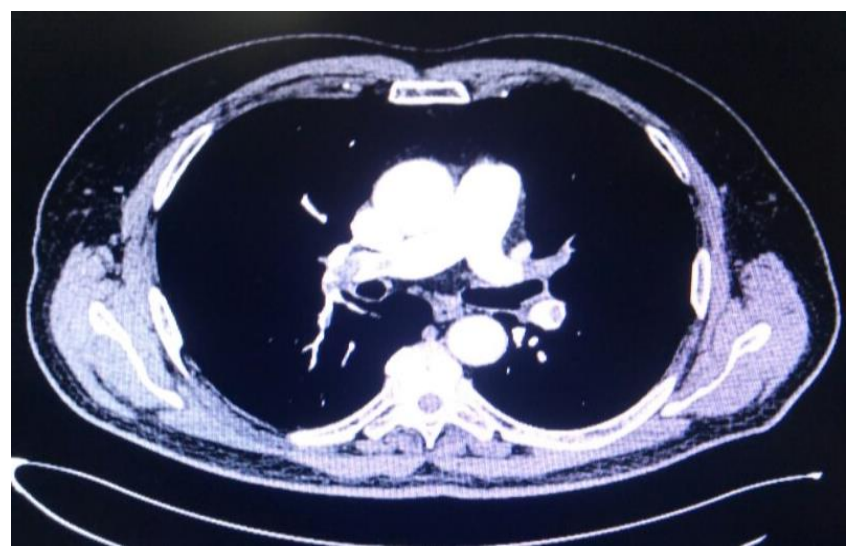

Figure 3: Computed tomography pulmonary angiography, axial images showing extensive bilateral pulmonary embolism in both main pulmonary arteries 


\section{AUTHOR CONTRIBUTIONS}

Concept - A.O., K.K., H.H.A., Ö.T., C.Ç.; Planning and Design - A.O., K.K., H.H.A., Ö.T., C.Ç.; Supervision A.O., K.K., H.H.A., Ö.T., C.Ç.; Funding - Ö.T., H.H.A.; Materials - C.Ç., Ö.T.; Data Collection and/or Processing - A.O., H.H.A., Ö.T.; Analysis and/or Interpretation - H.H.A., K.K.; Literature Review - A.O., H.H.A., K.K.; Writing - A.O., K.K., H.H.A., Ö.T., C.Ç.; Critical Review - A.O., K.K., H.H.A., Ö.T., C.Ç.

\section{YAZAR KATKILARI}

Fikir - A.O., K.K., H.H.A., Ö.T., C.Ç.; Tasarım ve Dizayn - A.O., K.K., H.H.A., Ö.T., C.Ç.; Denetleme - A.O., K.K., H.H.A., Ö.T., C.Ç.; Kaynaklar - Ö.T., H.H.A.; Malzemeler - C.Ç., Ö.T.; Veri Toplama ve/veya İşleme - A.O., H.H.A., Ö.T.; Analiz ve/veya Yorum - H.H.A., K.K.; Literatür Taraması - A.O., H.H.A., K.K.; Yazıyı Yazan - A.O., K.K., H.H.A., Ö.T., C.Ç.; Eleştirel İnceleme - A.O., K.K., H.H.A., Ö.T., C.Ç.

\section{REFERENCES}

1. Pollack CV, Schreiber D, Goldhaber SZ, Slattery D, Fanikos J, O'neil BJ, et al. Clinical characteristics, management, and outcomes of patients diagnosed with acute pulmonary embolism in the emergency department: initial report of EMPEROR (Multicenter Emergency Medicine Pulmonary Embolism in the Real World Registry). J Am Coll Cardiol 2011; 57:700-6. [CrossRef]

2. Stein PD, Henry JW, Relyea B. Untreated patients with pulmonary embolism: outcome, clinical, and laboratory assessment. Chest 1995; 107:931-5. [CrossRef]

3. Wells PS, Anderson DR, Rodger M, Ginsberg JS, Kearon $C$, Gent $M$, et al. Derivation of a simple clinical model to categorize patients probability of pulmonary embolism: increasing the models utility with the SimpliRED D-dimer. Thromb Haemost 2000; 83:416-20. [CrossRef]

4. Le Gal G, Righini M, Roy PM, Sanchez O, Aujesky D, Bounameaux $\mathrm{H}$, et al. Prediction of pulmonary embolism in the emergency department: the revised Geneva score. Ann Intern Med 2006; 144:165-71. [CrossRef]

5. van der Hulle T, Cheung WY, Kooij S, Beenen LFM, van Bemmel T, van Es J, et al. Simplified diagnostic management of suspected pulmonary embolism (the YEARS study): a prospective, multicentre, cohort study. Lancet 2017; 390:289-97. [CrossRef]

6. Quinn DA, Fogel RB, Smith CD, Laposata M, Thompson BT, Johnson SM, et al. D-dimers in the diagnosis of pulmonary embolism. Am J Respir Crit Care Med 1999; 159:1445-9. [CrossRef]

7. Taman SE, Abdelslam EM, Aboelkheir NY. Reliability of D-Dimer test results in deciding the necessity of performing CTA in high risk population to establish the diagnosis of PE. Egypt J Radio Nucl Med 2016; 47:501-7. [CrossRef]

8. Hendriksen JM, Lucassen WA, Erkens PM, Stoffers HE, van Weert $\mathrm{HC}$, Büller $\mathrm{HR}$, et al. Ruling out pulmonary embolism in primary care: comparison of the diagnostic performance of "Gestalt" and the Wells rule. Ann Fam Med 2016; 14:227-34. [CrossRef]

9. Penaloza A, Melot C, Motte S. Comparison of the Wells score with the simplified revised Geneva score for assessing pretest probability of pulmonary embolism. Thromb Res 2011; 127:81-4. [CrossRef]

10. Quezada CA, Zamarro C, Gómez V, Guerassimova S, Nieto R, Barbero $E$, et al. Clinical gestalt versus prognostic scores for prognostication of patients with acute symptomatic pulmonary embolism. Med Clin (Barc) 2018; 151:136-40. [CrossRef] 